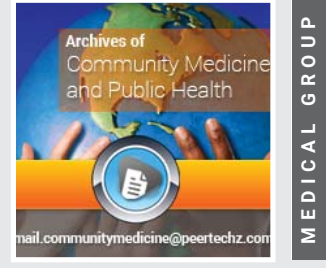

Short Communication

\section{Increasing the effectiveness of Virtual Learning during} COVID-19

\author{
Mahdieh Motie', Reza Dehnavieh² and Khalil Kalavani ${ }^{3 *}$ \\ ${ }^{1}$ MA Student in Nursing, Faculty of Nursing, Islamic Azad University of Tehran, Tehran, Iran \\ ${ }^{2}$ Associate Professor of Health Services Management, Head of Innovation Center, Institute for Future \\ Studies in Health, Kerman University of Medical Sciences, Kerman, Iran \\ ${ }^{3} \mathrm{PhD}$ Student in Health Services Management, Faculty of Healthcare Management, Student Research \\ Center, Kerman University of Medical Sciences, Kerman, Iran
}

Received: 27 June, 2020

Accepted: 10 August, 2020

Published: 11 August, 2020

*Corresponding author: Khalil Kalavani, Student Research Center, Department of Healthcare Management, Faculty of Healthcare Management, Kerman University of Medical Sciences, Kerman, Iran, Tel: +989373259329; E-mail:k.kalavani@kmu.ac.ir

https://www.peertechz.com

Check for updates
In recent decades we have seen a huge growth in higher education around the world. But the prevalence of COVID-19 put many problems in the school and universities and put them in serious challenges in various aspects of management [1]. Now the different methods that improve the learning process, gained interest in the many universities [2].

Now everyone is moving towards virtual learning and almost all educational institutions and universities in the world supplemented face-to-face instruction for their students, encouraging them to integrate online teaching and virtual education [1-3]. However, students often being less engaged in virtual learning than in face-to-face learning.

This note provides practical strategies to teachers and institutional heads who must manage the educational change of COVID-19. The most important point is how to maximize the effectiveness of virtual learning. To achieve this, educational methods must be based on creative approaches so that students are involved and active during virtual learning. In other words, several methods are running in the school and university for students [4-7], but, matters more than the training methods is how to implement it.

Our education needs to be more creative than ever. there are some examples of creative approaches such as:

Use of gamification in training: Use common elements of the game (for example, scoring, competing with others, rules of the game) in the field of education. The excitement of the game enters into training and learning is like a game.
Lesson storytelling: In this student-centered creative approach, the student teaches part of the training in the form of a story, novel, or summary for other students. Each student assumes a part in the training. increase the sense of responsibility in student cause to increase learning. This approach is suitable for theoretical courses whose references are clear.

Holding large online scientific competitions: These competitions are to encourage students to study their courses individually. These competitions can have different facilities (such as tuition discounts or cash prizes) for the students.

Group Activities: This extends more collaborative behavior and mutual learning.

The above examples are creative and non-traditional approach, and there may be many different methods. The main aim of this article is providing solutions to increase the effectiveness of training through creative approaches. It doesn't matter we do with which virtual learning software, but how we implement and teach it is, so important that we engage all students because they play an active role in learning.

Author contributions: All authors have read and approved to the manuscript.

\section{References}

1. Daniel SJ (2020) Education and the COVID-19 pandemic. Prospects 1-6. Link: https://bit.ly/2PFZDLm

2. Hakak S, Noor NF, Ayub MN, Affal H, Hussin N, et al. (2019) Cloud-assisted 
gamification for education and learning-Recent advances and challenges Computers \& Electrical Engineering 74: 22-34. Link: https://bit.ly/3itsChY

3. Yuen J, Xie F (2020) Medical education during the COVID-19 pandemic: perspectives from UK trainees. Postgrad Med 96: 432-433. Link: https://bit.ly/3adgzCn

4. Ferrel MN, Ryan JJ (2020) The impact of COVID-19 on medical education Cureus 12. Link: https://bit.ly/3ip6c0Z
5. Tokuç B, Varol G (2020) Medical Education in Turkey in the Time of COVID-19 Balkan Med J 37: 180-181. Link: https://bit.ly/2PFYZNW

6. Singh K, Srivastav S, Bhardwaj A, Dixit A, Misra S (2020) Medical Education During the COVID-19 Pandemic: A Single Institution Experience. Indian Pediatr 57: 678-679. Link: https://bit.ly/3knZSZw

7. Stuckey L, Wright A (2020) Innovations in Education in Response to COVID-19: Online Medication Commercials. Nurse Educator 45: 197. Link: https://bit.ly/3aa92nG
Discover a bigger Impact and Visibility of your article publication with

Peertechz Publications

\section{Highlights}

* Signatory publisher of ORCID

* Signatory Publisher of DORA (San Francisco Declaration on Research Assessment)

- Articles archived in worlds' renowned service providers such as Portico, CNKI, AGRIS, TDNet, Base (Bielefeld University Library), CrossRef, Scilit, J-Gate etc.

* Journals indexed in ICMJE, SHERPA/ROMEO, Google Scholar etc.

* OAI-PMH (Open Archives Initiative Protocol for Metadata Harvesting)

* Dedicated Editorial Board for every journa

* Accurate and rapid peer-review process

* Increased citations of published articles through promotions

* Reduced timeline for article publication

Submit your articles and experience a new surge in publication services

(https://www.peertechz.com/submission).

Peertechz journals wishes everlasting success in your every endeavours.

Copyright: @ 2020 Motie M, et al. This is an open-access article distributed under the terms of the Creative Commons Attribution License, which permits unrestricted use, distribution, and reproduction in any medium, provided the original author and source are credited. 